\title{
On Data and Care in Migration Contexts
}

\author{
Koen Leurs
}

[O]ur current political and sociotechnical moment sits at the forefront of philosophical questions about who cares, how they do it, and for what reason.

-Hi'ilei Julia Kawehipuaakahaopulani Hobart and Tamara Kneese $(2020,2)$

Offering fresh impetus to the emerging interdisciplinary research focus area of digital migration studies, this book probes how migration researchers, practitioners and policymakers can care for data. In taking a caring perspective, this book offers an important response to the recent trend of seeing migration as a laboratory where experiments with big data can be conducted. In particular, "irregularised migrants", the group of mobile subjects on which this anthology focuses, become guinea pigs. Experimental big-data-driven technosolutionism must be understood in a broader socio-political context where refugee and asylum migratory

K. Leurs $(\varangle)$

Department of Media and Culture, Utrecht University, Utrecht, The Netherlands e-mail: K.H.A.Leurs@uu.nl

(C) The Author(s) 2022

M. Sandberg et al. (eds.), Research Methodologies and Ethical Challenges in Digital Migration Studies, Approaches to Social Inequality and Difference, https://doi.org/10.1007/978-3-030-81226-3_9 
movements are taken to stage a crisis, e.g. the so-called "European migration crisis". Rather than caring for, under the heading of crisis, the key aim is increasingly to control mobile groups through datafied solutions. For example, Frontex, Europe's Border and Coast Guard Agency is carrying out research and innovation based on big-data-driven artificial intelligence (AI) as part of its "Integrated Border Management" (2021, 62), which seeks to identify, contain and deter particular mobile people. Technologies to be tested include "automated border control", "small autonomous unmanned aerial systems" and "geospatial data analytics of operational awareness" (ibid., 35-40). Refugee camps in Greece such as "Moria 2.0" become the EU's "sandbox for surveillance technologies", where data-driven securitisation plans include "camera surveillance with motion analysis algorithms monitoring the behavior and movement of centre residents" (Molnar 2021). The "long summer of migration" in 2015, and additional so-called migration crises, with Rohingya in Bangladesh, Venezuelans in Brazil and South Sudanese fleeing to Kenya, illustrate the allure of what we can call the "big data sublime" (Mosco 2004): assuming technological innovation can disrupt and solve problems (without having to come to terms with underpinning large-scale historical, socio-cultural, geo-political and economic concerns). The UN Special Rapporteur on Racism, Racial Discrimination, Xenophobia and Related Intolerance sums up by commenting that governments and UN agencies "are subjecting refugees, migrants, stateless persons and others to human-rights violations, and extracting large quantities of data from them on exploitative terms that strip these groups of fundamental human agency and dignity" (Achiume 2020, 1). In thinking further how we as critical, engaged migration, border and media researchers operate in this space, in this commentary, I draw out conceptual assumptions around the two main thematics of data and care that underpin the contributions of this field-setting book.

\section{DATA}

As a philosophical term, data can be etymologically traced back to the seventeenth century Latin plural of "datum", meaning literally "something given" (Lexico 2021). The assumption of (big) data as a given objective, a fixed and factual neutral rendering of reality, remains a key rallying point in heated academic and activist discussions. The notions of dataism and data colonialism have recently begun to dominate these 
discussions. Commonly understood as mutually exclusive analytic lenses, these opposite sides of the debate can lure researchers and others into the trap of feeling they must choose one or the other. On the one hand, the notion of dataism captures an ideological "belief in objective quantification" and "trust in the (institutional) agents" that gather, analyse and share data (Van Dijck 2014, 198; Harari 2017). From this perspective, data and algorithms gain increasing authority over decisionmaking practices. Ideologies of dataism are also apparent in some domains of academia, including migration studies, as well as migration management, policymaking and humanitarianism, as several chapters of this book demonstrate. For example, in Chapter 5, Laura Stielike convincingly critiques the exploitative machinic vision discernible in big-data-based knowledge production on migration. The assumption that "migration as something that needs to be governed and that can be better governed through better data" reflects the digital sublime aspect of dataism and illustrates how certain strands of migration research reinforce the assumption that contemporary migration is inherently tied to database-driven governmentality.

The concept of "data colonialism" has grown into a prominent alternative critical framework. Jim Thatcher, David O'Sullivan and Dillon Mahmoudi proposed the term to dismantle utopian imaginaries of "digital frontierism" and grasp "accumulation by dispossession" $(2016,990)$. In a similar vein, Nick Couldry and Ulises A. Mejias draw on the term to address datafication as a new expansive formation of capitalism: "data relations enact a new form of data colonialism, normalizing the exploitation of human beings through data" $(2019,336)$. There is a growing body of work critiquing experimental governmentality projects that colonise datafied migrant populations under the heading of crisis management, securitisation and risk mitigation or "data-driven humanitarianism" (e.g. Molnar 2019). The book also delves further into the oppressive and exploitative data relations observable in the field of migration.

To account for the multiplicity, heterogeneity and inherent situatedness of data, datafication and data practices, Stefania Milan and Emiliano Treré rightly invite scholars to move beyond data universalisms such as dataism and data colonialism (2019). They argue that "the main problem with data universalism is that it is asocial and ahistorical, presenting technology (and datafication-related dynamics, we add) as something operating outside of history and of specific sociopolitical, cultural, and economic contexts" $(2019,324)$ and call for epistemic diversity and most 
importantly epistemic justice. Stefano Calzati similarly argues that to operationalise "pluralisation" of our understandings of data, we should speak about dataisms and data colonialisms $(2020,4)$.

This book proposes various ways to address data as inherently situated, contextualised and partial forms of representation and narratives. To draw out this understanding further, we can take cues from established theories on the performativity of language and performativity of images. Following J. L. Austin's book How to do things with words? (1962) we can draw on speech-act theory to conceptually pursue the question How to do things with data? In addition, we can address how data stretches across narrative and visual domains by taking cues from W. J. T. Mitchell's book What do pictures want? to ask What is said about data? And what does data want? For this purpose, in the remainder of this section, I will take the following 4 steps, (I) discuss some of the theoretical premises of performativity, (II) address performativity vis-à-vis power relations, (III) explicate how these processes are constituted through digital networks and datafication and (IV) transpose these insights into the specific context of datafied migration.

I. For the language philosopher John L. Austin, particular types of discourse can be understood as illocutionary acts. Illocutionary acts are performative utterances such as, for example, "You're fired", "I apologise", "You are under arrest" or "I now pronounce you married". Depending on the person making these statements and the contexts in which they are made, these speech acts result in a changed state of affairs or change in our relationships and social world: "The uttering of a performative is, or is part of, the doing of a certain kind of action, the performance of which, again, would not normally be described as just 'saying' or 'describing' something” (Austin 1962, 5). Besides Austin's language philosophy, theories of performativity have been developed in phenomenology and existentialism, ethnomethodology as well as theatre and performance studies (Isin 2021).

II. Theories of power in relation to performativity have been developed in queer and black feminism, poststructuralism, decolonial and postcolonial studies, and science and technology studies (Isin 2021). Articulating the relationship between discourse, gender normativity, sexuality and racism, Judith Butler conceptualised how performativity is inherently power-ridden. With her notion of the performative, Butler goes beyond distinctions between material-embodied and symbolic-discursive domains. Gender performativity is the constitutive stylised repetitious 
process through which one acquires a gendered subjectivity: "language sustains the body not by bringing it into being or feeding it in a literal way; rather, it is by being interpellated within the terms of language that a certain social existence of the body first becomes possible" (Butler 1997, 6). Performativity establishes and reinforces power relations through "the repetition or citation of a prior, authoritative set of practices" (Butler $1993,226)$. However, theories of performativity seek to create awareness of how room manoeuvre, contestation and agency always remain. For Butler, gender can, for example, be subverted by unsettling and denaturalising it as "an act $[\ldots]$ which is open to splitting, self-parody, self-criticism” (1990, 282).

III. In recent years, several scholars have taken up performativity as a critical lens to address big data and datafication. Taking the example of databased search procedures, Rita Raley understands datafied surveillance (dataveillance) as a performative process: "Our data bodies [...] are repeatedly enacted. Data is in this respect performative: the composition of flecks and bits of data into a profile" $(2013,218)$. Larissa Hjorth illustrates how families do digital kinship, they also take up dataveillance as an empowering form of agency, to find reassurance in being able to monitor and share mundane performative activities over distance (2021). Focussing on performativity as agential, Engin Isin and Evelyn Ruppert have theorised digital citizenship as a form of politics in their reflection on "how people perform themselves as political subjects by making digital rights claims $[\ldots]$ by saying and doing something through the internet" (2020, xi).

IV. Drawing on Butler's notion of citationality, Tobias Matzner specifies how normativity shapes the performative big-data forms of migration governance (2016). For Matzner, through its diagnoses, or "verdicts", big data develop a "subjectivising force", for example, in the context of border control or processing mobile populations. Through that, they install hierarchy as they "cite a particular norm to count as a subject in the first place": a subject who is allowed to pass or needs to be stopped at a border, a subject allowed or denied a visa or allowed to board a plane (2016, 206-207). Vassilis S. Tsianos and Brigitta Kuster have called for critical scrutiny of datafied migration, while emphasising "doing digital borders", which emphasises the digital "performativity of the border" $(2016,237)$. From a separate angle, Stephan Scheel, Evelyn Ruppert and Funda Ustek-Spilda address the increasing data-driven knowledge making 
practices of migration across policy and academic domains into performative enactments (2019). As the processual understanding of "migrants' digital space" by Vasiliki Makrygianni, Ahmad Kamal, Luca Rossi and Vasilis Galis (Chapter 2) illustrates, the present book adopts a constructivist view of the performativity of data practices in migration. The book shows this perspective has the potential to reveal the intricate interplay between how the oppressive workings of technological systems, which variously play out, are contested and negotiated in the everyday lived experiences of distinctively situated mobile groups.

\section{CARING FOR (BIG) DATA}

After having articulated further alternative, nuanced and holistic understandings of data as performative, we now turn to the second key term underpinning the book: care. Marie Sandberg and Luca Rossi propose that for digital migration researchers "approaching migrants' digital data collection 'with care' means pursuing a more critical approach to the use of big data in migration research where the data is not an unquestionable proxy for social activity" (in the introductory chapter for this book). Here, they base their productive thoughts on Annemarie Mol's understanding of "care in practice" as a heterogeneous process resulting from a myriad of socio-material actors interacting in specific conditional settings (Mol et al. 2010). Sandberg and Rossi call for a theory and ethics of careful data research in and on migration, and below I address some genealogies to further situate the potentialities of pursuing caring migration data relations.

From an etymological perspective, we can trace caring to the Old English verb of "carian", which is of Germanic origin; and can be related to Old High German words "chara", meaning "grief, lament" and the Old Norse word "kor", meaning "sickbed" (Lexico 2021). Commonsensical understandings of care revolve around forms of provision reflecting what is needed for the health, welfare, maintenance and protection of something or someone; as well as attention applied to doing something right and avoiding damage or risk (Lexico 2021). Over time, these various meanings have lingered variously in care projects, and have exacerbated and deepened inequalities and hierarchies. Daniela Agostinho recognises the potential of care as a generative framework for critical "thinking about life and livability under digital and datafied conditions", but quite rightly 
cautions that "the racial, gendered, and colonial histories of care make it a difficult concept to think and work with" (2021, 80-81).

Historically, care is a term strongly reconceptualised by feminist theorists, elevating it from its previous marginalised feminine rendering of care duties to a lens for scrutinising academic knowledge production practices. A ground-breaking feminist definition of care was proposed by Joan Tronto and Bernice Fisher, who prioritised care as a material moral foundation to serve reproduction of socially just human life:

On the most general level, we suggest that caring be viewed as a species activity that includes everything that we do to maintain, continue, and repair our 'world' so that we can live in it as well as possible. That world includes our bodies, our selves, and our environment all of which we seek to interweave in a complex, life-sustaining web. $(1990,40)$

Like the practice-oriented understanding of data discussed above, caring can first be seen as an active practice revolving around the basic aims of survival, sustaining capabilities and avoiding suffering. Ethics of care is further premised on the moral dimensions of attentiveness, responsibility, competence and responsiveness (Tronto and Fisher 1990). Caring is often perceived as dominantly other-oriented, but self-care should also be recognised as a legitimate aim, and it functions as a prerequisite for providing care to others (Engster 2005). When informing research practice, a feminist ethics of care potentially provides a paradigm change, in offering alternative guidelines for conducting ethical human-centric research.

Feminist sociologists Rosalind Edwards and Melanie Mauthner offer a productive set of guiding questions that can assist researchers in translating feminist ethics of care ideals into their research practice:

- Who are the people involved in and affected by the ethical dilemma raised in the research?

- What is the context of the dilemma in terms of the specific topic of the research and the issues it raises personally and socially for those involved?

- What are the specific social and personal locations of the people involved in relation to each other?

- What are the needs of those involved and how are they interrelated?

- Who am I identifying with, who am I posing as otherwise, and why? 
- What is the balance of personal and social power between those involved?

- How will those involved understand our actions and are these in balance with our judgement about our own practices?

- How can we best communicate the ethical dilemmas to those involved, give them room to raise their views, and negotiate with and between them?

- How will our actions affect relationships between the people involved? (2002, 28-29)

These questions are generative to pursue reflecting on the ambiguous "tinkering" practices that for Mol, Moser and Pols constitute care relations with all technologies (2010).

These questions invite researchers to engage in a reflexive mode of knowledge production on digital migration. Ethics of care concerns include obstacles, refusals as well as positionalities of researchers and research communities, which are often not explicitly addressed in published research output or conference presentations. Elsewhere, colleagues and I have critiqued this process under the heading of "dirty methods" (Bivens, Harvey, Leurs, Luka, Milette, Shepherd, forthcoming) where we argue "students are expected to learn how to do research through imitation, largely as a form of individualized apprenticeship, and consult methodological textbooks that offer clean, rigid, and disembodied recipes but pay little attention to the management of personal, collaborative, and bodily experiences, sensations, and anxieties" (ibid). With the notion of dirty methods, we seek to make generative the careful messiness and tinkering that is inherent in all research encounters.

In this book, (Chapter 6) Leandros Fischer and Martin Bak Jørgensen, Vasilis Galis (Chapter 7) and Ninna Nyberg Sørensen (Chapter 8) either implicitly or explicitly draw on ethics of care principles to articulate their own concerns as they seek to grapple with doing digital data research on migration with migrants. For example, Galis as well as Fischer and Jørgensen reflect on the role of academics and how they may be implicated in the migration industry, and whether, in avoiding complicity, researchers are required to become militant researchers. Another pivotal discussion concerns becoming aware of the plural subject position of researchers and the parallel need to attend to the plurality of informants' lives. Galis and Nyberg Sørensen highlight the complex emotional intensities of fieldwork for the various different types of bodies involved. An 
additional important reflexive step to be considered here could be to embrace all research perspectives as "partial perspectives" (Haraway 1988, 575). Following the thoughts of Donna Haraway, there is an inherent partiality in all research endeavours, therefore an ethical step could be to account for how decision-making and explicitly specifying how knowledge produced has come from somewhere, is being shaped by specific personal, emotional and epistemological trajectories, gatekeeping procedures and standpoints (Haraway 1988). To illustrate the importance of foregrounding partiality, Fischer and Bak Jørgensen (Chapter 6) propose to operationalise caring digital research with mobile populations by drawing on Maurice Stierl, who provocatively argues that doing engaged research with migrants should amplify the epistemic crisis of European governmentality. For Stierl, "Do harm could be the motto for a critical and impactful scholarship of migration" $(2020,16)$. Fisher and Bak Jørgensen argue that in a politicised landscape, it is important to take explicit sides in social justice research, as not taking sides under the heading of objectivity may lead to the further silencing of already marginalised voices. By not taking sides, researchers are therefore implicated in the migration industry, contributing to an exclusionary and often violent, oppressive structure.

Further cues to reflect about and engage in caring relations with data may be gleaned from emerging discussions in feminist data studies and critical migration studies. In critical migration studies, Stephan Scheel and his colleagues reflect on care as a form of ethical accountability. They reflect on practicing three modes of care developed as part of their collaborative research project "thinking with others", "tinkering with field notes" and "dissenting within" $(2020,522)$. They built on Puig de la Bellacasa's relational understanding of care in knowledge production, understanding care as an "ontological requirement of relational worlds" $(2012,199)$. This aspect of relationality also shapes Marie Sandberg, Nina Grønlykke Mollerup and Luca Rossi's scrutiny of narrating mobility and bordering through "thin" social media and "thick" ethnographic data (Chapter 3).

In feminist media and data studies, several scholars have further developed such a situated, responsive and careful approach to, for example, social media data analysis (e.g. Luka and Millette 2018).

So how should performative approaches to data and ethics of care be juxtaposed to stimulate creative debate? To operationalise a caring approach to (big) data, let us start with Catherine D'Ignazio and Lauren 
F. Klein's seven data feminism principles: (I) Examine power, (II) Challenge power, (III) Elevate emotion and embodiment, (IV) Rethink binaries and hierarchies, (V) Embrace pluralism, (VI) Consider context and (VII) Make labour visible (2020, 17-18). A commitment to power, reflexivity and situatedness underpins these principles. Margie Cheesman's research on the role and imaginaries of blockchain in the refugee camps of Azraq and Zaatari in Jordan demonstrates the strong potential of such a situated, collaborative and careful research encounter with "irregularised migrants" on datafication. She grounds trust in blockchain technology by listening to refugee women and learning how they interpret their experiences through faith-based concepts. Research informants contest the datafication and digitisation of aid provision using the Islamic concept of "barakah" بركة to address the felt temporal inconsistency, immateriality and dependability of digital as opposed to cash assistance (Cheesman 2021). Future digital migration studies research can build on additional recently developed more situated, reflexive and affective forms of data studies, for example, taking the form of "data diaries" (Tkacz et al. 2021), the data "walkthrough method" (Light, Burgess and Duguay 2018), smartphone and social-media scroll-back methodologies (Georgiou and Leurs, Forthcoming 2021) and "data walking" (Van Es and de Lange 2020).

\section{Conclusions}

Migration, irregularised migration in particular, is shaped by a variety of human and non-human actors that sustain either care, securitisation or both. Care and securitisation are increasingly outsourced through automation, datafication and machinic vision. This volume breaks new ground by offering the means to reflect on the role of researchers at this conjuncture. In the present comment, I offer several genealogies of data and care, key themes that underpin the theorisation, methodological and ethical operationalisation of a more caring digital migration studies described in this book. Overall, the essays included urge us to go against the grain and rethink care-datafication technologies not as binary oppositions but as fundamentally relational. Also, in specifically situated contexts of datafication of irregularised migration, care is not to be seen as the absolute opposite of data. Rather, as the contributors show, pursuing careful data engagement allows understanding and 
reflection on the "ambivalence and shifting tensions" inherent in caretechnology relations (Mol et al. 2010, 14). The genealogies discussed in the chapter remind us that neither migration nor data nor care are singular totalities. Social justice-oriented research on migration demands reflexive, situated and engaged careful tinkering with informants across scales and with human and non-human actors, to begin to come to terms with the paradoxes of data performativity. Data sets promise neutrality and total knowledgeability, but they are fundamentally ambiguous, power-ridden and "uncertain archives" (Bonde Thylstrup et al. 2021), with potentially humanising, dehumanising and abusive consequences for migrant subjects. Further scrutiny is required concerning the implications of the inherent uncertainty of data sets, of missing data, of the datafication of affect, and the politics of inclusion and exclusion that data encodes and challenges. In order to research datafied migration differently and sustain a caring, human-centric, profound and critical focus in the area of digital migration studies, we must encourage interdisciplinary dialogue between critical border and migration studies, social media studies, anthropology of migration, science and technology studies, critical data studies, feminist, queer and anti-racist theory.

\section{BIBLIOGRAPHY}

Achiume, E. Tendayie. 2020. "Report of the Special Rapporteur on Contemporary Forms of Racism, Racial Discrimination, Xenophobia and Related Intolerance." United Nations. Office of the High Commissioner, A/75/590. Retrieved from: https://www.ohchr.org/EN/newyork/Documents/A-75590-AUV.docx.

Agostinho, Daniela. 2021. "Care." In Uncertain Archives: Critical Keywords for Big Data, edited by N. B. Thylstrup et al., 75-86. Cambridge, MA: MIT Press.

Austin, John L. 1962. How to Do Things with Words. Oxford: Oxford University Press.

Bivens, R., A. Harvey, K. Leurs, M. E. Luka, M. Milette, and T. Shepherd. Forthcoming. Dirty Methods. Waterloo, ON: Wilfred Laurier Press.

Butler, Judith. 1993. Bodies That Matter: On the Discursive Limits of "Sex." New York, NY: Routledge.

Butler, Judith. 1997. Excitable Speech: A Politics of the Performative. New York, NY: Routledge. 
Butler, Judith. 1990. Gender Trouble: Feminism and the Subversion of Identity. New York, NY: Routledge.

Calzati, Stefano. 2020. "Decolonising 'Data Colonialism' Propositions for Investigating the Realpolitik of Today's Networked Ecology." Television \& New Media. Online first https://doi.org/10.1177/1527476420957267.

Cheesman, Margie. 2021. "Reconceptualising Blockchain in Aid: From Trust in Institutions to Faith in Infrastructure." Paper presented at Digital Practices and the Everyday conference, panel 'Southern' responses to digital tech in (forced) migration. Utrecht University, the Netherlands, April 22, 2021.

Couldry, Nick, and Ulises A. Mejias. 2019. "Data Colonialism: Rethinking Big Data's Relation to the Contemporary Subject." Television \& New Media 20 (4): 336-349.

D'ignazio, Catherine, and Lauren F. Klein. 2020. Data Feminism. Cambridge, MA: MIT Press.

Edwards, Rosalind, and Melanie Mauthner. 2002. "Ethics and Feminist Research: Theory and Practice." In Ethics in Qualitative Research, edited by $M$. Mauthner, M. Birch, J. Jessop, and T. Miller, 14-31. London: Sage.

Engster, Daniel. 2005. "Rethinking Care Theory: The Practice of Caring and the Obligation to Care." Hypatia 20: 50-74.

Frontex. 2021. "Artificial Intelligence-Based Capabilities for the European Border and Coast Guard." Retrieved from: https://frontex.europa.eu/ media-centre/news/news-release/artificial-intelligence-based-capabilities-foreuropean-border-and-coast-guard-1Dczge.

Georgiou, M., and Koen Leurs. Forthcoming 2021. "Smartphones as Personal Digital Archives? Recentering Migrant Authority as Curating and Storytelling Subjects." Journalism: Theory, Practice \& Criticism, special issue Flesh Witnessing: Smartphones, UGC and Embodiment, edited by Lilie Chouliaraki, and Mette Mortensen.

Harari, Yuval N. 2017. Homo Deus: A Brief History of Tomorrow. UK: Vintage Penguin Random House.

Haraway, Donna. 1988. "Situated Knowledges: The Science Question in Feminism and the Privilege of Partial Perspective." Feminist Studies 14 (3): 575-599.

Hjorth, Larissa. 2021. "Digital Kinship-Understanding Familial Care at a Distance: Keynote Migrant Belongings. Digital Practices and the Everyday Conference." Utrecht University, the Netherlands, 22 April 2021. Retrieved from https://www.youtube.com/watch?v=1YKdbYVKTd0.

Isin, Engin. 2021. "Digital Citizens Yet to Come." Digital Practices and the Everyday conference. Utrecht University, the Netherlands, 22 April 2021. Retrieved from https://www.youtube.com/watch?v=WGyTEZ5GpGY.

Isin, Engin, and Evelyn Ruppert. 2020. Being Digital Citizens. 2nd ed. London: Rowman \& Littlefield. 
Kawehipuaakahaopulani Hobart, H. J., and T. Kneese. (2020). Radical Care: Survival Strategies for Uncertain Times. Social Text 38 (1): 1-16.

Lexico. 2021. "UK Dictionary". Oxford University Press. Retrieved from: https://www.lexico.com/definition/.

Light, Ben, Jena Burgess, and Stefanie Duguay. 2018. "The Walkthrough Method: An Approach to the Study of Apps." New Media \& Society 20 (3): 881-900.

Luka, Mary E., and Mélanie Millette. 2018. "(Re)Framing Big Data: Activating Situated Knowledges and a Feminist Ethics of Care in Social Media Research.” Social Media + Society. https://doi.org/10.1177/2056305118768297.

Matzner, Tobias. 2016. "Beyond Data as Representation: The Performativity of Big Data in Surveillance." Surveillance \& Society 14 (2): 197-210.

Milan, Stefania, and Emiliano Treré. 2019. "Big Data from the South(s): Beyond Data Universalism." Television \& New Media 20 (4): 319-335.

Mol, Annemarie, Ingunn Moser, and Jeanettte Pols. 2010. "Care: Putting Practice into Theory." In Care in Practice: On Tinkering in Clinics, Homes and Farms, edited by A. Mol, I. Moser, and J. Pols, 7-26. Bielefeld: Transcript Verlag.

Molnar, Petra. 2019. "New Technologies in Migration: Human Rights Impacts." Forced Migration Review, June 7-9.

Molnar, Petra. 2021. "Moria 2.0: The Eu's Sandbox for Surveillance Technologies." Euractiv. Retrieved from: https://www.euractiv.com/section/digital/ news/moria-2-0-the-eus-sandbox-for-surveillance-technologies/.

Mosco, Vincent. 2004. The Digital Sublime. Cambridge, MA: MIT Press.

Puig de la Bellacasa, Maria. 2012. "Nothing Comes Without Its World': Thinking with Care." The Sociological Review 60 (2): 197-216.

Raley, Rita. 2013. "Dataveillance and Counterveillance." In Raw Data Is an Oxymoron, edited by Lisa Gitelman, 121-146. Cambridge, MA: MIT Press.

Scheel, Stephan, Francisca Grommeé, Evelyn Ruppert, F. Ustek-Spilda, B. Cakici, and V. Takala. 2020. Doing a Transversal Method: Developing an Ethics of Care in a Collaborative Research Project. Global Networks 20: 522-543.

Scheel, S., E. Ruppert, and Funda Ustek-Spilda. 2019. "Enacting Migration Through Data Practices." Environment and Planning D: Society and Space 37 (4): 579-588.

Stierl, Maurice. 2020. "Do No Harm? The Impact of Policy on Migration Scholarship." Environment and Planning C: Politics and Space, 2399654420965567.

Thatcher, Jim, David O'Sullivan, and Dillon Mahmoudi. 2016. Data Colonialism through Accumulation by Dispossession: New Metaphors for Daily Data. Environment and Planning D: Society and Space 34 (6): 990-1006. 
Thylstrup, Bonde et al. 2021. "Big Data as Uncertain Archives." In Uncertain Archives: Critical Keywords for Big Data, edited by Nanna B. Thylstrup et al., 1-28. Cambridge, MA: MIT press.

Tkacz, Nathaniel, Mário da Mata Martins, Joao de Albuquerque, Flavio Horita, and D. Givanni Neto. 2021. "Data Diaries: A Situated Approach to the Study of Data." Big Data \& Society. https://doi.org/10.1177/205395172 1996036.

Tronto, Joan C., and Berenice Fisher. 1990. "Toward a Feminist Theory of Caring." In Circles of Care, edited by E. Abel and M. Nelson, 36-54. SUNY Press.

Tsianos, Vasilis S., and B. Brigitte Kuster. 2016. "Eurodac in Times of Bigness: The Power of Big Data Within the Emerging European IT Agency." Journal of Borderlands Studies 31 (2): 235-249.

Van Dijck, José. 2014. "Datafication, Dataism and Dataveillance: Big Data between Scientific Paradigm and Ideology." Surveillance \& Society 12 (2): 197-208.

Van Es, Karin, and Michiel de Lange. 2020. "Data with Its Boots on the Ground: Datawalking as Research Method." European Journal of Communication 35 (3): 278-289.

Open Access This chapter is licensed under the terms of the Creative Commons Attribution 4.0 International License (http://creativecommons.org/licenses/ by $/ 4.0 /$ ), which permits use, sharing, adaptation, distribution and reproduction in any medium or format, as long as you give appropriate credit to the original author(s) and the source, provide a link to the Creative Commons license and indicate if changes were made.

The images or other third party material in this chapter are included in the chapter's Creative Commons license, unless indicated otherwise in a credit line to the material. If material is not included in the chapter's Creative Commons license and your intended use is not permitted by statutory regulation or exceeds the permitted use, you will need to obtain permission directly from the copyright holder.

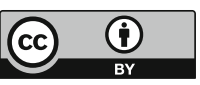

